\title{
Ox-LDL Influences Peripheral Th17/Treg Balance by Modulating Treg Apoptosis and Th17 Proliferation in Atherosclerotic Cerebral Infarction
}

\author{
Qing Lia Yiping Wange Hongqi Li ${ }^{b}$ Guodong Shen ${ }^{c, d}$ Shilian Hu ${ }^{c, d}$ \\ aThe Central Laboratory of Medical Research Center, ${ }^{b}$ Department of Cadre's ward1, 'Department of \\ Geriatrics, The Affiliated Provincial Hospital of Anhui Medical University, Hefei, China; dAnhui Provincial \\ Key Laboratory of Tumor Immunotherapy and Nutrition Therapy, Hefei, China; ${ }^{\text {eThe Centre for }}$ \\ Transplantation and Renal Research, Western Clinical School, University of Sydney, Westmead, Australia
}

\section{Key Words}

Cerebral infarction - Oxidized low-density lipoprotein - T helper $17 \cdot$ Regulatory $\mathrm{T}$ cells, Apoptosis • Proliferation

\begin{abstract}
Background: $\mathrm{CD} 4{ }^{+} \mathrm{CD} 25^{+}$regulatory $\mathrm{T}$ (Treg) cells and T-helper 17 (Th17) cells play important roles in acute cerebral infarction (ACI). Our previous findings have suggested that oxidized low-density lipoprotein (Ox-LDL) could influence Treg/Th17 ratio in ACI patients. However, the mechanisms are still not clear. Methods and Results: We evaluated the effects of oxLDL on Th17/Treg cell apoptosis and proliferation in vitro. Our results demonstrated that with increased ox-LDL concentrations, the frequency and suppressive function of Treg cells was decreased while the frequency of Th17 cells was elevated in control subjects. In addition, AnnexinV ${ }^{+}$apoptotic rate, Fas/Fas ligand (FasL) expression, and Caspase- 3 activity were escalated in Treg cells while were no significant changes in Th17 cells. Simultaneously, 5-Bromo-29-Deoxyuridine (BrdU) and 3-(4,5-Dimethylthiazol-2-yl)-2,5-Diphenyl Tetrazolium Bromide (MTT) incorporation of Th17 cells was elevated accompanied by upregulated nuclear factor- $\mathrm{KB}$ (NF-kB) activity. However, Th17 proliferation was decreased when pre-incubated with Pyrrolidine dithiocarbamate (PDTC, inhibitor of NF-KB activation). Furthermore, there were significant changes induced by ox-LDL in Treg apoptosis, Fas/FasL/Caspase-3 expression of Treg cells, and Th17 proliferation, NF-KB activation of Th17 in ACI patients than in patients with transient ischemic attack (TIA) and control subjects $(P<0.01, P<0.05$ respectively). Conclusion: These data support that ox-LDL may influence the Th17/Treg balance by modulating Fasmediated Treg apoptosis and NF-KB-associated Th17 proliferation. Ox-LDL also induced a more significant alteration of Treg and Th17 in ACI patients than in TIA and control groups, suggesting a novel role in the pathogenesis of $\mathrm{ACI}$.
\end{abstract}




\section{Introduction}

Atherosclerosis (AS) is a chronic inflammatory disease which involves various immune cells, particularly T lymphocytes, such as $\mathrm{CD} 4^{+} \mathrm{T}$-helper cells $[1,2]$. Acute cerebral infarction (ACI) is a major cause of disability and death worldwide. ACI results from plaque erosion and interruption of blood supply to regions of the brain, which leads to ischaemia of brain tissue, cell damage and cell death. In contrast to ACI, transient ischemic attack (TIA) involves the sudden and brief loss of cerebral or ocular function, due to ischemic causes, with complete recovery. AS and plaque rupture are the principal causes of ACI and TIA, and T lymphocytes play an important role in these coronary events $[3,4]$.

$\mathrm{CD}^{+} \mathrm{T}$ cells may differentiate into different lineages characterized by their secretion of different cytokines. $\mathrm{CD} 4^{+} \mathrm{CD} 25^{+}$regulatory $\mathrm{T}$ (Treg) cells and T-helper 17 (Th17) cells have recently been described as two original subsets distinguished from Th1 and Th2 cells. Treg cells, characterized by the expression of the forkhead/winged helix transcription factor (Foxp3), are essential for the control of self-tolerance and exhibit an anti-inflammatory function by contact-dependent suppression or by the release of anti-inflammatory cytokines [5]. Th17 cells which express retinoic acid-related orphan receptor $\gamma \mathrm{t}(\mathrm{ROR} \gamma \mathrm{t}$ ) play critical roles in the development of autoimmune diseases and human inflammatory conditions by producing a novel cytokine, interleukin (IL)-17 [6]. The Th17/Treg imbalance may play an important role in atherosclerotic plaque inflammation and destabilization in animal models $[7,8]$. Studies in humans from others, as well as our previous studies, have also suggested a Th17/Treg imbalance in patients with acute coronary syndrome and ACI $[9,10]$. However, to the best of our knowledge, a possible cause for the Th17/Treg imbalance in human atherosclerotic plaque formation/destabilization has not been explored in depth.

Oxidized low-density lipoprotein (Ox-LDL) is a pivotal factor in the pathogenesis of progressive AS and contributes to plaque rupture and thrombosis through multiple mechanisms [11]. Our previous findings have suggested that ox-LDL could elevate Th17 expression while decreasing Treg expression [12], and ox-LDL induced a more significant alteration of Treg and Th17 cells from ACI patients than in the TIA and control groups in vitro [10]. Ox-LDL may contribute to plaque destabilisation and ACI occurrence by its effects on this balance. However, the reasons underlying this effect of ox-LDL on Th17/Treg cells in ACI are not clear yet.

Activation-induced cell death is a major mechanism of peripheral $\mathrm{T}$ cell apoptosis in which Fas/ Fas ligand (FasL) pathway plays an important role [13]. Furthermore, we had previously seen distinctly different sensitivity of Treg/Th17 cells to Fas-mediated apoptosis [14]. Meier et al. [15] have demonstrated that ox-LDL activates Treg apoptosis in patients with end-stage renal disease through Fas engagement.

Ox-LDL has also been shown to be a compound capable of inducing proliferation in the absence of any other mitogenic factors [16]. Nuclear factor kappa B (NF- $\kappa B$ ) is a family of dimeric transcription factors (usually RelA/p65:p50). In most cells NF- $\kappa B$ transcription factors appear to mediate survival signals that protect cells from apoptosis. Moreover, the NF$\kappa \mathrm{B}$ signaling pathway has been shown to promote proliferation of rat cardiac fibroblasts and cancer cells $[17,18]$. Ox-LDL activates NF- $\kappa B$ in endothelial cells, monocytes/macrophages and vascular smooth muscle cells, causing increases in its activity and expression, which consequently results in the up-regulation of pro-inflammatory cytokines [19].

Therefore, we postulated that, in ACI patients, ox-LDL may influence peripheral Th17/ Treg imbalance by modulating Fas-mediated apoptosis and NF-кB-related proliferation. The aim of the current investigation was to verify in a large group of patients that the role of oxLDL on Th17/Treg balance exerts in ACI. Moreover, we also aimed to explore the mechanisms of the effect of ox-LDL on Th17/Treg cell apoptosis and proliferation in vitro. 


\section{Materials and Methods}

\section{Study population}

The study was approved by the Ethics Committee of Anhui Medical University and conforms with the declaration of Helsinki and its amendments. All patients gave written informed consent before enrollment into this study. This study was cross-sectional and blinded. We examined patients at Anhui provincial hospital who underwent diagnostic catheterisation (112 male and 80 female) between December 2009 and November 2012. Patients were classified into three groups: Group 1, atherosclerotic cerebral infarction (ACI) patients (38 male and 29 female; mean age, 61.3 12.9 years). The diagnosis was based on a modification of the TOAST criteria based on the clinical, radiographic, and diagnostic information available [20]. Group 2 , transient ischemic attacks (TIA) patients (39 male and 26 female, mean age $59.1 \pm 14.2$ years), TIA was defined as a documented neurological deficit lasting $<24$ hours without definite radiographic evidence of acute ischemia [21]. Group 3, control subjects (35 male and 25 female; mean age, $56.9 \pm 16.1$ years), control subjects with repeated episodes of dizziness were selected on a basis of recent angiography showing normal carotid arteries. Patients with ACI and TIA had a similar extent of carotid atherosclerosis. There were no significant differences of age between the three groups.

No patient was treated with anti-inflammatory drugs and/or immunosuppressive agents. None had intracranial hemorrhage, brain abscess, surgery, or trauma, thromboembolism, disseminated intravascular coagulation, advanced liver disease, renal failure, malignant disease, other inflammatory disease, chronicimmune-mediated disorders, congestive heart failure.

\section{Blood samples and cell preparation}

Peripheral blood (5-10 ml) was collected from all the patients, in a fasting state, on the morning following admission. The time interval between symptom onset and blood sampling was less than $24 \mathrm{~h}$ in all cases. Peripheral blood mononuclear cells (PBMCs) were prepared by Ficoll density gradient centrifugation for further analysis. Serum was obtained after centrifugation and stored at $-80^{\circ} \mathrm{C}$ until further use.

\section{Detection of Treg and Th17 cells}

For the analysis of Treg cells, cell surface staining was performed by the use of APC-conjugated antiCD4 (Beckman Coulter-Immunotech, France), PE-Cy7-conjugated anti-CD25 (Immunotech), PerCP-Cy5.5conjugated anti-CD127 (eBioscience, USA) and appropriate isotype controls. Cells were incubated with antibodies for $20 \mathrm{~min}$ at room temperature in the dark, followed by washing in phosphate buffered solution (PBS). Cells were fixed and permeabilized with the Fix/Perm reagent, incubated with PE-conjugated antiFoxp3 (eBioscience) and its isotype control, washed with PBS and analyzed by flow cytometry (FCM).

For Th17 analysis, ox-LDL-induced PBMCs were suspended at a density of $2.0 \times 10^{6}$ cells $/ \mathrm{ml}$ in complete culture medium (Gibco BRL, USA). Cultures were stimulated with phorbol myristate acetate (PMA, $25 \mathrm{ng} /$ $\mathrm{ml})$ plus ionomycin $(1 \mu \mathrm{g} / \mathrm{ml})$ for $4 \mathrm{~h}$ at $37^{\circ} \mathrm{C}$ and $5 \% \mathrm{CO}_{2}$, in the presence of monensin $(1.7 \mu \mathrm{g} / \mathrm{ml}$, all from Alexis Biochemicals, USA). After incubation, the cells were labeled with APC-conjugated anti-CD4 for 20 min and then stained with PE-Cy7-conjugated anti-IL-17A (eBioscience) after fixation and permeabilization according to the manufacturer's instructions. Stained cells were assessed by FCM using BD FACS Aria II flow cytometer (Becton Dickinson, USA). The frequency of Treg $\left(\mathrm{CD} 4^{+} \mathrm{CD} 25^{+} \mathrm{Foxp} 3^{+}\right.$and CD $\left.4^{+} \mathrm{CD} 25^{+} \mathrm{CD} 127^{\text {low }}\right)$ and Th17 $\left(\mathrm{CD} 4^{+} \mathrm{IL} 7^{+}\right)$cells was expressed as a percentage of $\mathrm{CD} 4^{+} \mathrm{T}$ cells by sequential gating on lymphocytes and $\mathrm{CD}^{+}{ }^{+} \mathrm{T}$ cells.

Functional Assay of Treg cells

$\mathrm{CD} 4^{+} \mathrm{CD} 25^{+} \mathrm{CD} 127^{\text {low }}$ and $\mathrm{CD} 4^{+} \mathrm{CD} 25^{-}$cells were sorted on the FACS Aria II cell-sorter. Freshly purified $\mathrm{CD} 4^{+} \mathrm{CD} 25^{+} \mathrm{CD} 127^{\text {low }} \mathrm{T}$ cells from controls and patients ( $\mathrm{n}=10$ in each group) were assayed for their suppressive activity in the allogeneic mixed lymphocyte response assay. Irradiated (3000 rad) PBMCs from healthy controls were used as allogeneic stimulator cells. $\mathrm{CD} 4^{+} \mathrm{CD} 25^{-}$cells were used as responder cells. CD $4^{+} \mathrm{CD} 25^{-}$cells $\left(1.0 \times 10^{4}\right.$ cells per well $)$ were co-cultured with $\mathrm{CD} 4^{+} \mathrm{CD} 25^{+} \mathrm{CD} 127^{\text {low }}$ cells $\left(1.0 \times 10^{4}\right.$ cells per well, 1:1 ratio) in the presence of irradiated PBMCs $\left(2.0 \times 10^{4}\right.$ cells per well $)$ in a 96-well flat-bottom plate. Wells without $\mathrm{CD} 4^{+} \mathrm{CD} 25^{+} \mathrm{CD} 127^{\text {low }}$ cells (responders and stimulators only) served as positive controls. Wells containing $\mathrm{CD} 4^{+} \mathrm{CD} 25^{+} \mathrm{CD} 127^{\text {low }}$ cells and irradiated PBMCs (none-responders) served as baseline controls. All incubations were run in triplicate with a final volume of $150 \mu \mathrm{l}$ at $37^{\circ} \mathrm{C}$ and $5 \% \mathrm{CO}_{2}$. After $48 \mathrm{~h}$ 
of incubation, $10 \mu$ l Cell Proliferation Reagent WST-1 was added to each well. After incubation for a further $4 \mathrm{~h}$, the absorbance of the samples against a background control as blank was measured at $450 \mathrm{~nm}$ using $650 \mathrm{~nm}$ as a reference wavelength on a Biocell HT1 microplate reader (Salzburg, Austria). Suppression was expressed as a percentage of the positive control.

Measurement of blood biochemistry and ox-LDL in Serum

Blood glucose and lipids were determined by the enzymatic method. All of the assays were conducted on an Olympus AU2700 biochemical autoanalyzer (Olympus, Japan). The levels of ox-LDL in serum were examined by the enzyme-linked immunosorbent assay (ELISA) and measured at $450 \mathrm{~nm}$ on microplate reader (ox-LDL ELISA kits from Uscnlife, USA). The minimal detectable concentrations were 4.5 $\mu \mathrm{g} / \mathrm{L}$ for ox-LDL. Intra- and inter-assay coefficients of variation were $<5 \%$. All samples were measured in duplicate.

Preparation of $L D L$ and $o x-L D L$

Blood was collected in EDTA (1 mg/mL) from healthy controls after a 12-hour fast. LDL (density=1.019 to $1.063 \mathrm{~g} / \mathrm{mL}$ ) was isolated from plasma after density adjustment with $\mathrm{KBr}$ and preparative ultracentrifugation at $50000 \mathrm{rpm}$ for 22 hours with a type 50 rotor. The LDL preparation was dialyzed against $0.15 \mathrm{~mol} / \mathrm{L}$ EDTA ( $\mathrm{pH}$ 7.4), filtered through $0.22 \mu \mathrm{m}$ filters and stored under nitrogen in the dark [22]. For oxidation, the LDL was diluted to $0.1 \mathrm{mg}$ protein/mL with EDTA-free PBS and incubated with $5 \mu \mathrm{mol} / \mathrm{L}$ CuSO4 for 24 hours at $22^{\circ} \mathrm{C}$. Control incubations were done in the presence of $0.1 \mathrm{mmol} / \mathrm{L}$ EDTA without CuSO4. At the end of incubation, $0.1 \mathrm{mmol} / \mathrm{L}$ EDTA was added to prevent further oxidation [23].

Lipoprotein oxidation was confirmed by analysis of thiobarbituric acid reactive substances (TBARS). TBARS-concentration was calculated using malondialdehyde (MDA) standard curve and expressed as nmol MDA equivalents /mg of LDL protein [24]. The levels of TBARS in ox-LDL were $41.9 \pm 3.2 \mathrm{nmol} / \mathrm{mg}$ protein $(\mathrm{n}=5)$ compared with $3.6 \pm 0.4 \mathrm{nmol} / \mathrm{mg}$ protein $(\mathrm{n}=5)$ in native LDL. Ox-LDL was stored at $4^{\circ} \mathrm{C}$ for about 4 weeks in darkness and sealed tubes prior to its use.

Ox-LDL induction experiments

PBMCs $\left(1.0 \times 10^{6}\right.$ cells $\left./ \mathrm{ml}\right)$ from control subjects $(\mathrm{n}=10)$ were incubated with various concentrations of ox-LDL $(0,1,5,10,50,100 \mu \mathrm{g} / \mathrm{ml})$ for $48 \mathrm{~h}$ in vitro. To compare the effects of ox-LDL on Treg and Th17 cells from ACI, TIA and control group, PBMCs from each group $(\mathrm{n}=10)$ were incubated with $1 \mu \mathrm{g} / \mathrm{ml}$ ox-LDL.

Cells were cultured in triplicate in U-bottom 96-well plates in RPMI supplemented with $10 \%$ fetal bovine serum, During experiments, Cells were incubated for $48 \mathrm{~h}$ before being washed in warm sterile PBS to remove the oxidant. After incubation, Treg/Th17 frequencies and the suppressive functions of Tregs were assessed.

Analysis of the effect of ox-LDL on apoptosis of Treg and Th17

Cell staining for AnnexinV: Apoptosis analysis in Treg and Th17 cells after induction. Apoptotic cells of Treg and Th17 after incubation were identified by staining for AnnexinV with an apoptosis detection Kit (BD Pharmingen, USA). For Treg apoptosis analysis, aliquots $(100 \mu \mathrm{L})$ of cells were incubated with $20 \mu \mathrm{L}$ of APC-anti-CD4, PerCP-Cy5.5-anti-CD25 and PE-Cy7-anti-CD127 for 20min. Cells were then washed with PBS and suspended in $100 \mu \mathrm{L}$ binding buffer. After incubation with $5 \mu \mathrm{L}$ FITC-AnnexinV for 15 min at room temperature, cells were resuspended in $400 \mu \mathrm{L}$ binding buffer and analyzed by FCM. For Th17 apoptosis analysis, the cells were stained with APC-anti-CD4 for $20 \mathrm{~min}$, then incubated with $5 \mu \mathrm{L}$ FITC-AnnexinV for $20 \mathrm{~min}$. After fixation and permeabilization, cells were stained with PE-Cy7-anti-IL-17A. In order to evaluate the influence of in vitro stimulation and fixation/permeabilization on cell apoptosis, CD4+ $\mathrm{T}$ cell apoptosis was examined among groups under pre-stimulation, post-stimulation, and post-fixation/permeabilization.

Fas and FasL expression in Treg and Th17 cells. Fas and FasL expression of Treg/Th17 cells was measured after incubation. As for Treg analysis, cell surface staining was performed by the use of FITC-antiFas (eBioscience), PE- anti-FasL (eBioscience), APC-anti-CD4, PE-cy7-anti-CD25, PerCP-Cy5.5-anti-CD127. Antibodies and appropriate isotype controls were incubated with cells for $20 \mathrm{~min}$ at room temperature in the dark. For Th17 analysis, the cells were incubated with FITC-anti-Fas, PE-anti-FasL, APC- anti-CD4 for $20 \mathrm{~min}$, then were stained with PE-cy7-anti-IL-17A after fixation and permeabilization. Stained cells were assessed by FCM. The frequency of Fas and FasL in Treg (CD4 $\left.{ }^{+} \mathrm{CD} 25^{+} \mathrm{CD} 127^{\text {low }}\right)$ and Th17(CD4 ${ }^{+}$IL17 $\left.{ }^{+}\right) \mathrm{T}$ cells was expressed as a percentage of Treg or Th17 by gating on Treg or Th17 cells. 
Measurement of caspase-3 activity in Treg cells. After culture, intracellular caspase-3 activity in Treg cells was detected by active Caspase- 3 apoptosis Kit (Pharmingen). Purified PBMCs $\left(1 \times 10^{6}\right.$ cells $\left./ \mathrm{mL}\right)$ were stained with APC-anti-CD4, PE-cy7-anti-CD25, PerCP-Cy5.5-anti-CD127 for $20 \mathrm{~min}$, then cells were fixed and permeabilized after washing in PBS. At last, cells were stained with FITC-conjugated anti-active Caspase-3 antibody for $30 \mathrm{~min}$, and analyzed by FCM.

\section{Analysis of the effect of ox-LDL on Th17 proliferation and $N F-\kappa B$ activation}

For Th17 differentiation CD4 ${ }^{+} \mathrm{T}$ cells were isolated from PBMCs ( $\mathrm{n}=10$ from each group) by FACS Aria II cell-sorter. To generate Th17 cells, purified $\mathrm{CD}^{+} \mathrm{T}$ cells were stimulated with plastic-bound antiCD3 and anti-CD28 in $25 \mathrm{~cm}^{2}$ tissue culture flasks and cultured in complete culture medium (Invitrogen) supplemented with anti-IFN- $\gamma(10 \mu \mathrm{g} / \mathrm{ml})$, anti-IL-4 $(10 \mu \mathrm{g} / \mathrm{ml})$, recombinant human IL-1 $\beta(10 \mathrm{ng} / \mathrm{ml})$, IL-6 (20 ng/ml), IL-23 (10 ng/ml) (all from R\&D Systems) for 5 days. The resultant viable Th17 cells were restimulated with PMA and ionomycin for $4 \mathrm{~h}$ for determination of IL-17 production, or were cultured in complete culture medium 24 -well plates $\left(10^{6}\right.$ cells per well $)$ to stimulation. With pre-treatment or not pretreatment with $10 \mu \mathrm{M}$ Pyrrolidine dithiocarbamate (PDTC, inhibitor of NF- $\mathrm{BB}$ activation) for 1h, Th17 cells from control group were incubated in vitro in the presence of plastic-bound anti-CD3 /anti-CD28, and coincubated with various concentrations of ox-LDL $(0,1,5,10,50,100 \mu \mathrm{g} / \mathrm{ml})$ for $48 \mathrm{~h}$. To compare the effects of ox-LDL on Th17 proliferation from ACI, TIA and control group, Th17 cells from all the three groups were incubated with $1 \mu \mathrm{g} / \mathrm{ml}$ ox-LDL for $48 \mathrm{~h}$.

\section{Proliferation assay: 5-Bromo-29-Deoxyuridine (BrdU) Incorporation}

Proliferation was evaluated by measuring the incorporation of BrdU into newly synthesized DNA. Uptake of BrdU into differentiated Th17 cells and its incorporation into DNA were determined by ELISA. Th17 cells $\left(1.0 \times 10^{6}\right.$ cells $)$ were seeded onto 96 -well plates and incubated at $37^{\circ} \mathrm{C}$ for $2 \mathrm{~h}$ after the addition of $10 \mu \mathrm{M}$ BrdU in FBS-free culture medium. Next, the cells were incubated for $30 \mathrm{~min}$ at room temperature in fixative solution and then in the blocking reagent included in the assay kit. Peroxidase-labeled anti-BrdU monoclonal antibody solution was added and incubated for $90 \mathrm{~min}$ at room temperature. After the cells were washed three times with PBS for $5 \mathrm{~min}$, substrate solution was added and the cells were incubated for $30 \mathrm{~min}$ at room temperature. The reaction was stopped by the addition of $1 \mathrm{M}$ sulphuric acid, and the optical density of each sample at $450 \mathrm{~nm}$ was measured by using microplate reader. Proliferation was expressed as a percentage of absorbance of the treated cells to the absorbance of the non-treated control cells.

Proliferation assay: 3-(4,5-Dimethylthiazol-2-yl)-2,5-Diphenyl Tetrazolium Bromide (MTT) Incorporation

After the cultures were incubated at $37^{\circ} \mathrm{C}, 5 \% \mathrm{CO}_{2}$ with for $48 \mathrm{~h}$, Th17 proliferation in cultures was appraised by an MTT assay. After the addition of RPMI 1640 medium containing $10 \%$ MTT, the cells were incubated at $37^{\circ} \mathrm{C}$ for $4 \mathrm{~h}$, the medium was aspirated, and the cells were lysed by the addition of $100 \mu \mathrm{l}$ dimethylsulfoxide (DMSO). Then, $10 \mu \mathrm{l}$ was collected from each sample and diluted in $90 \mu \mathrm{l}$ of fresh DMSO. The absorbance was read on ELISA microplate reader at $490 \mathrm{~nm}$. The results are presented as the average absorbance and expressed as the mean of triplicate samples.

Western blot analysis

NF- $\kappa \mathrm{B}$ activity was analyzed by Western blotting. After treatment of Th17 cells with ox-LDL, the cells were harvested and nuclear extracts were collected by using a nuclear extraction kit (Millipore, Billerica, USA) according to the manufacturer's instructions. The nuclear protein concentration was determined. $40 \mu \mathrm{g}$ of nuclear protein sample from each group was separated on 10\% SDS-polyacrylamide gel electrophoresis and transferred to polyvinylidene difluoride membrane. The membrane was blocked and probed with antibodies against NF- $\mathrm{kB}$ (p65) (Boster, Wuhan, China) or proliferating cell nuclear antigen (PCNA) overnight at $4^{\circ} \mathrm{C}$. Antibody recognition was detected with peroxidase-conjugated secondary antibodies (Pierce) at room temperature for $60 \mathrm{~min}$. The immunoreactive bands were visualized by enhanced chemiluminescence reagent with PCNA as the internal control. Three independent experiments were performed, and the results were reproducible.

\section{Statistical analysis}

Values were expressed as the mean \pm SD. Data were analysed by using SPSS 13.0 software (Chicago, IL, USA). The significance of differences was assessed by one-way analysis of variance (ANOVA) followed 
Table 1. Patient characteristics. Values are expressed as mean $\pm \mathrm{SD}$ or number. ACI: acute cerebral infarction; TIA: Transient ischemic attacks; NCA: subjects with normal carotid arteries; BFG: blood-fasting glucose; TC: total cholesterol; TG: total triglyceride; HDL-C high-density lipoprotein cholesterol; LDL-C: low density lipoprotein cholesterol. a) $P<0.05$ vs. Control; b) $P<0.01$ vs. Control

\begin{tabular}{llll}
\hline Item & Control $(\mathrm{n}=60)$ & TIA $(\mathrm{n}=65)$ & ACI $(\mathrm{n}=67)$ \\
\hline Age & $56.9 \pm 16.1$ & $59.1 \pm 14.2$ & $61.3 \pm 12.9$ \\
Gender (male/female) & $35 / 25$ & $39 / 26$ & $38 / 29$ \\
Hypertension, n (\%) & $25(41.7)$ & $30(46.1)$ & $32(47.8)$ \\
Smoking rate, n (\%) & $18(30)$ & $21(32.3)$ & $24(35.7)$ \\
BFG (mmol/L) & $4.94 \pm 0.52$ & $5.48 \pm 0.86^{\mathrm{a}}$ & $5.56 \pm 0.93 \mathrm{a}$ \\
TC (mmol/L) & $4.41 \pm 0.63$ & $5.13 \pm 0.78 \mathrm{~b}$ & $5.27 \pm 0.89 \mathrm{~b}$ \\
TG (mmol/L) & $1.09 \pm 0.41$ & $1.67 \pm 0.54 \mathrm{a}$ & $1.85 \pm 0.52 \mathrm{~b}$ \\
HDL-C (mmol/L) & $1.28 \pm 0.13$ & $1.02 \pm 0.25$ & $1.08 \pm 0.27$ \\
LDL-C (mmol/L) & $2.43 \pm 0.39$ & $2.96 \pm 0.51 \mathrm{a}$ & $3.19 \pm 0.74 \mathrm{~b}$ \\
\hline
\end{tabular}

by Bonferroni or Dunnett's C multiple comparison tests. Spearman's correlation was used as a test of correlation between two continuous variables. $P<0.05$ was considered to be statistically significant.

\section{Results}

\section{Characteristics of patients}

There were no significant differences in age, gender, hypertension, coronary disease, smoking rate and high density lipoprotein-cholesterol (HDL-C) concentrations between the three groups. However, blood-fasting glucose (BFG), total cholesterol (TC) and total triglyceride (TG), low density lipoprotein cholesterol (LDL-C) levels in the ACI and TIA groups were significantly higher than those in the control group $(P<0.05$ and $P<0.01$, respectively). There were also no significant differences in BFG, TC, TG, LDL-C concentrations between the ACI and TIA group (Table 1).

Correlation of serum ox-LDL levels to Th17/Treg cells in ACI patients

As shown in Fig. $1 \mathrm{~A}$, the frequencies of Treg cells $\left(\mathrm{CD} 4^{+} \mathrm{CD} 25^{+} \mathrm{Foxp}^{+} / \mathrm{CD}^{+} \mathrm{T}\right.$ cells) were significantly lower in ACI patients $(1.73 \pm 0.45 \%)$ than in TIA patients $(2.65 \pm 0.41 \%)$ and control subjects $(3.86 \pm 0.54 \%)(P<0.05, P<0.01$ respectively $)$. The frequencies of Treg cells in TIA patients were also markedly lower than in the control group $(P<0.01)$. On the contrary, the frequencies of Th17 cells (CD4 ${ }^{+} \mathrm{IL} 17^{+} / \mathrm{CD} 4^{+} \mathrm{T}$ cells) were markedly higher in ACI patients $(3.91 \pm 0.62 \%)$ than in TIA patients $(2.38 \pm 0.43 \%)$ and control subjects $(0.97$ $\pm 0.28 \%$ )(both $P<0.01$ ). There was also an obvious difference between the TIA and control groups $(P<0.01)$.

Freshly purified Treg cells from controls and patients were assayed for their suppressive activity by MLR assay. Suppressive rates of Treg cells were markedly lower in ACI patients $(39.2 \pm 3.4 \%)$ than in TIA patients $(63.8 \pm 4.5 \%)$ and controls $(82.7 \pm 5.1 \%)$ (both $P<0.01)$. Suppressive rates of Treg cells were also significantly lower in TIA patients than in control group $(P<0.05)$.

The concentration of ox-LDL was significantly greater in ACI patients $(438.40 \pm 59.10$ $\mu \mathrm{g} / \mathrm{L})$ than in TIA patients $(367.20 \pm 44.30 \mu \mathrm{g} / \mathrm{L})$ and control subjects $(312.50 \pm 37.40 \mu \mathrm{g} / \mathrm{L})$ $(P<0.05, P<0.01$ respectively). There was also an obvious difference between the TIA and control groups $(P<0.05)$.

In addition, ox-LDL concentrations in serum were negatively correlated with the frequency of Treg cells $(P<0.01$ and $r=-0.726)$, and positively correlated with the frequency of Th17 cells $(P<0.01$ and $r=0.753$, Fig. 1B).

Effects of ox-LDL on Treg apoptosis and Th17 proliferation in control subjects in vitro

We examined the effects of ox-LDL at various concentrations on the numbers of Treg and Th17 cells in control subjects. With increased ox-LDL concentrations, the frequency 
A
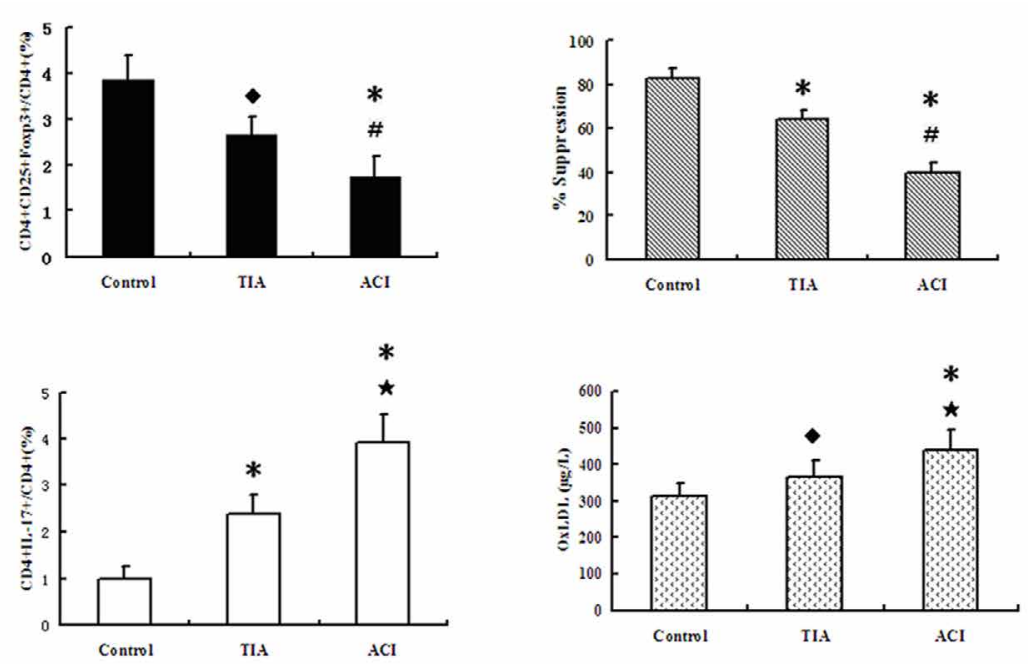

$\mathrm{B}$
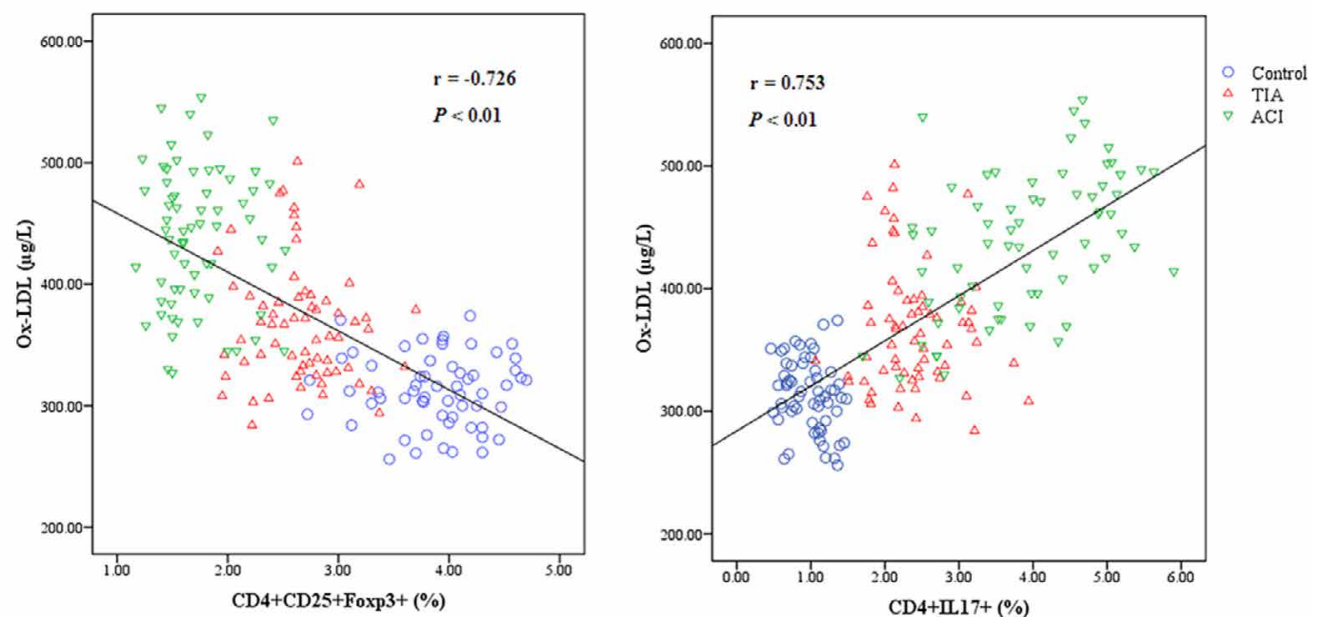

Fig. 1. Correlation of serum ox-LDL levels to Treg/Th17 expression in ACI patients. Treg frequencies and function were decreased and Th17 Frequencies were increased in patients with ACI. (A) Comparison of Treg/ Th17 expression, Treg function and ox-LDL concentration in serum among the ACI, TIA and control groups. $\bullet P<0.05$ vs. Control; ${ }^{*} P<0.01$ vs. Control; ${ }^{\sharp} P<0.05$ vs. TIA; ${ }^{\star} P<0.01$ vs. TIA. (B) Ox-LDL concentrations in serum were negatively correlated with the frequency of Treg cells and positively correlated with the frequency of Th17 cells.

and suppressive function of Treg cells was decreased while the frequency of Th17 cells was elevated (Fig. 2A). In addition, AnnexinV ${ }^{+}$apoptotic cells, Fas/FasL expression, and Caspase-3 activity in Treg cells was escalated while AnnexinV $\mathrm{V}^{+}$apoptotic cells and Fas/ FasL expression in Th17 cells was no significant change (Fig. 2B). In the control test of apoptosis analysis in Th17 cells, $\mathrm{CD}^{+} \mathrm{T}$ cells apoptosis was not significantly altered in the post-stimulation group or the post-fixation/permeabilization group in comparison to the pre-stimulation group $(P>0.05)$.

We examined the effects of ox-LDL on proliferation of differentiated Th17 by BrdU incorporation and MTT assay. With increased ox-LDL concentrations, the BrdU and MTT incorporation of Th17 cells was elevated accompanied by upgraded NF- $\kappa$ B activity. Furthermore, Th17 proliferation was declined when pre-incubated with PTDC. These data show that ox-LDL stimulated Th17 proliferation in a concentration-dependent manner, which may be associated with NF- $\mathrm{BB}$ activation (Fig. 3). 


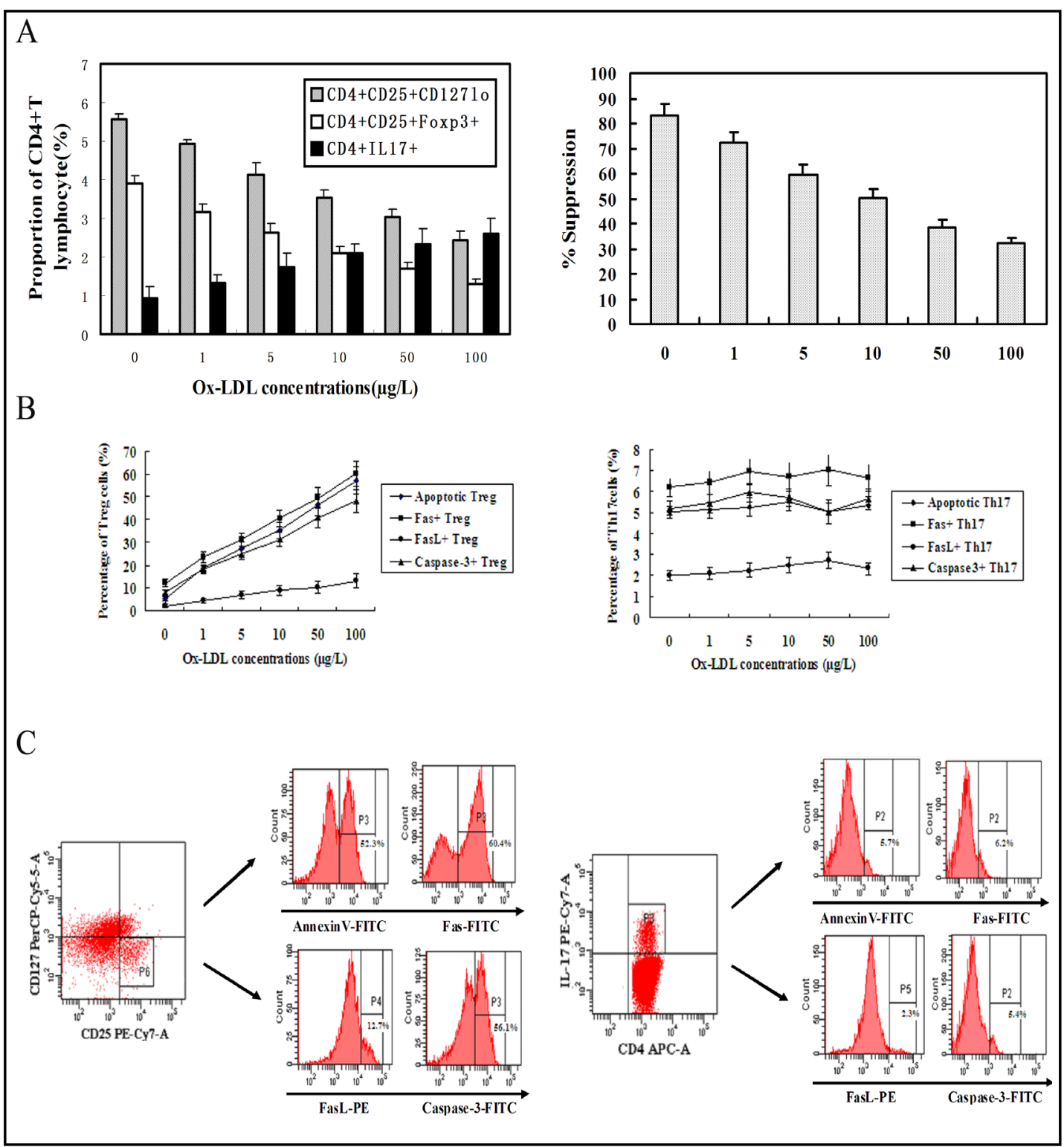

Fig. 2. Effect of ox-LDL on the expression of Treg and Th17 cells from control subjects. (A) PBMCs from control subjects $(n=10)$ were incubated with different concentrations of ox-LDL for $48 \mathrm{~h}$. With increased ox-LDL concentrations, the frequency of Treg cells was decreased while the frequency of Th17 cells was elevated. (B) With increased ox-LDL concentrations, Treg cells exhibited a remarkable increase in apoptotic rate, Fas/ FasL expression and Caspase-3 activity, but there were no marked changes in these indicators of Th17 cells. (C) The flow cytometry plots about apoptotic cells, Fas, FasL and active Caspase- 3 expression in Treg cells (gated by $\mathrm{CD} 4{ }^{+} \mathrm{CD} 25^{+} \mathrm{CD} 127^{\text {low }}$ cells) and Th17 (gated by CD4+IL-17 ${ }^{+}$cells).

\section{Effects of ox-LDL on Treg and Th17 expression in ACI patients in vitro}

We investigated the sensitivity of the ox-LDL-mediated decrease of Treg cells, compromise of function and increase of Th17 cells in the ACI, TIA, and control groups. There were significant changes in the number of Treg and Th17 cells in the presence of ox-LDL in patients with ACI than in TIA and control subjects. In addition, there were also significant changes in the number of Treg and Th17 cells induced by ox-LDL in patients with TIA, but not in controls (Fig. 4). However, there was no difference in the numbers of $\mathrm{CD} 4^{+}$cells in cultured PBMCs derived from ACI and TIA patients and control subjects treated with ox-LDL. 


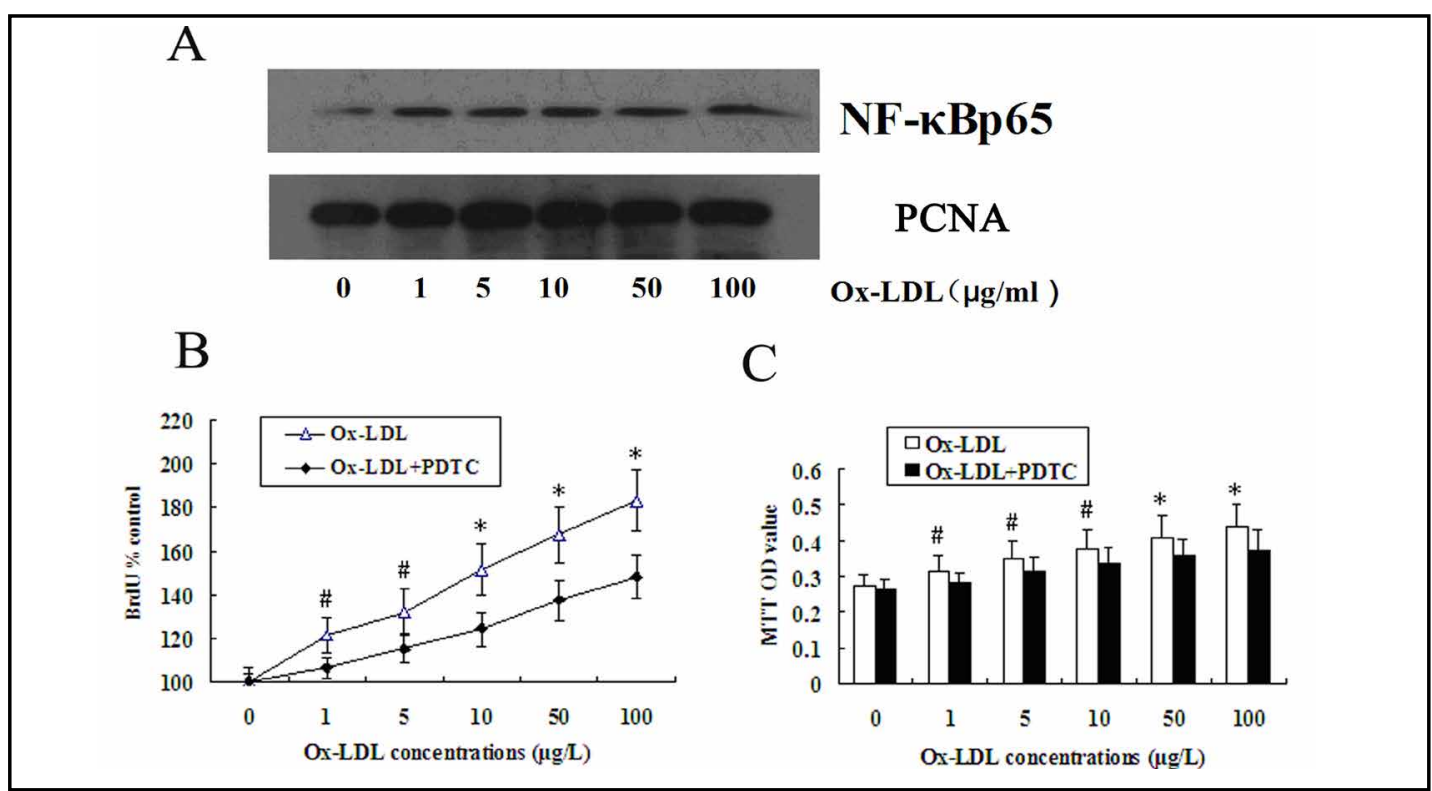

Fig. 3. Ox-LDL induced Th17 proliferation in a dose-dependent manner, which could be suppress by Pyrrolidine dithiocarbamate (PDTC), an inhibitor of Nuclear factor kappa B (NF- $\kappa B$ ). (A) Involvement of NF- $\kappa B$ nuclear translocation in ox-LDL-stimulated proliferation of Th17 after $48 \mathrm{~h}$ culture. NF- $\kappa \mathrm{B}$ nuclear translocation after ox-LDL treatment at various doses by Western blot. BrdU incorporation (B) and MTT assay (C) for differentiated Th17 was performed after induced by ox-LDL at various concentrations for $48 \mathrm{~h}$, in the case of pre-treatment and not pre-treatment with PDTC. Cells treated with vehicle (PBS) were considered to be baseline (100\%) in BrdU incorporation ( ${ }^{*} p<0.01$ vs. PDTC-treatment group; $\# p<0.05$ vs. PDTC-treatment group; all experiments $\mathrm{n}=10$ from the control group).

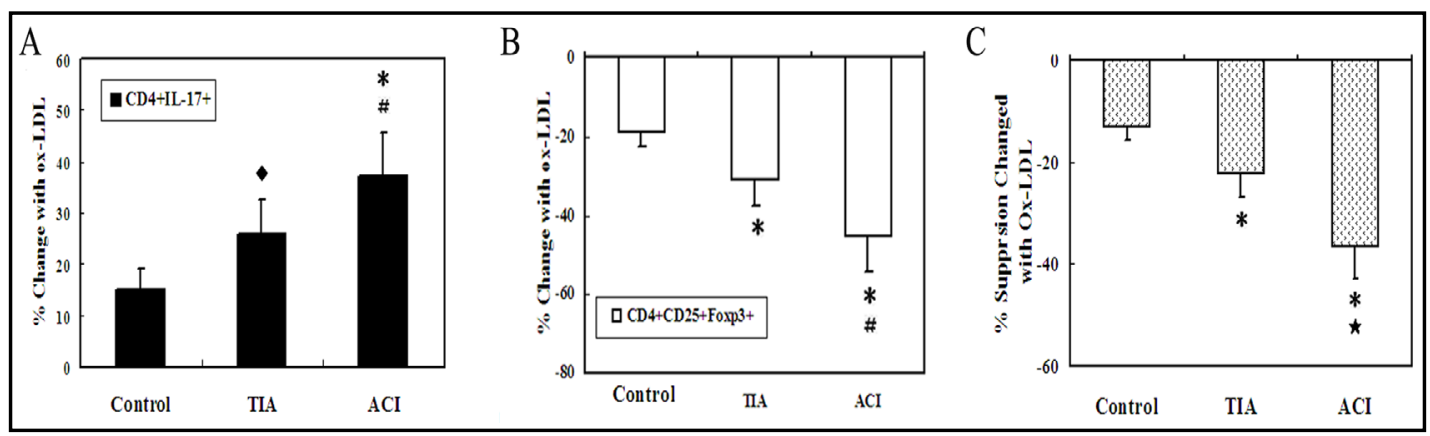

Fig. 4. Ox-LDL induces a more evident alteration of Treg and Th17 cells from ACI and TIA patients. Co-culture assay was performed as described in the Methods section, PBMCs from the ACI, TIA and control groups ( $\mathrm{n}=10$ in each group) were incubated with $1.0 \mu \mathrm{g} / \mathrm{ml}$ ox-LDL for $48 \mathrm{~h}$. Average change of Th17 (A) and Treg (B) numbers in three groups after a $48 \mathrm{~h}$ co-culture with $1.0 \mu \mathrm{g} / \mathrm{ml}$ ox-LDL. ${ }^{*} P<0.01$ vs. Control; ${ }^{\bullet} P<0.05$ vs. Control; ${ }^{\#}<0.05$ vs. TIA. (C) Average attenuation of the suppressive function of Treg cells in three groups when exposed to ox-LDL. ${ }^{*} P<0.01$ vs. Control; ${ }^{\star} P<0.01$ vs. TIA.

In addition, the suppressive functions of Treg cells from all the three groups were compromised after exposure to ox-LDL. Incubation of Treg cells with $1 \mu \mathrm{g} / \mathrm{mL}$ ox-LDL, resulted in a significant attenuation of their ability to suppress the proliferation of Treg cells $(P<0.05$ for control and $P<0.01$ for TIA and ACI). It is noteworthy that attenuation of the suppressive properties of Treg cells in ACI patients was also more apparent than in TIA patients and controls (both $P<0.01$ ). In addition, there were significant differences in Treg function between the TIA and control group $(P<0.01$; Fig. 4). 
Fig. 5. Effects of ox-LDL on Treg apoptosis and Th17 proliferation from ACI patients. (A) AnnexinV $V^{+}$ apoptotic cells, Fas/FasL expression, and Caspase-3 activity for Treg and Th17 cells induced by 1.0 $\mu \mathrm{g} / \mathrm{ml} \quad$ ox-LDL in the ACI, TIA and control groups $\quad(\mathrm{n}=10$ in each group). ${ }^{*} P<0.01$ vs. control; $\bullet P<$ 0.05 vs. Control; ${ }^{\star} P<0.01$ vs. TIA; ${ }^{\# P}<$ 0.05 vs. TIA. (B) NF-kB nuclear translocation after oxLDL treatment was determined by

\section{A}

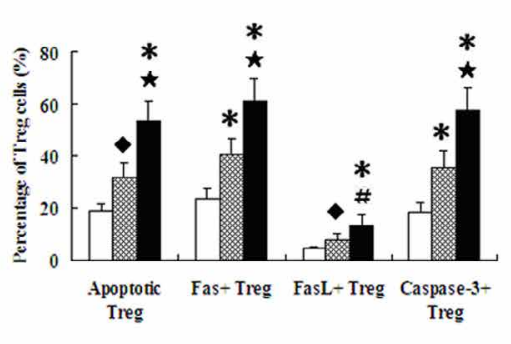

B

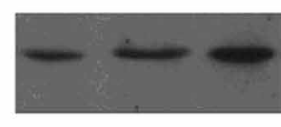

NF-кBp65

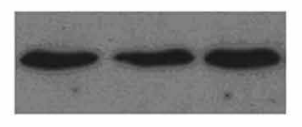

PCNA

Control TIA ACI

C

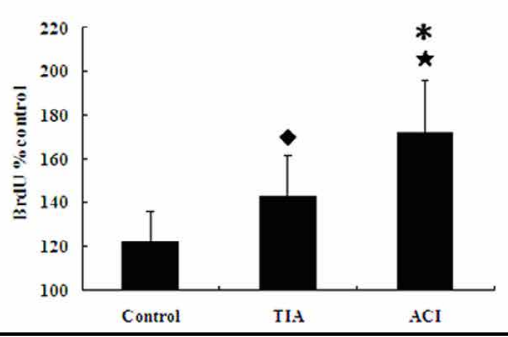

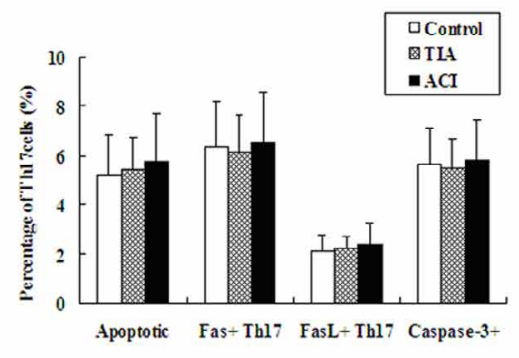
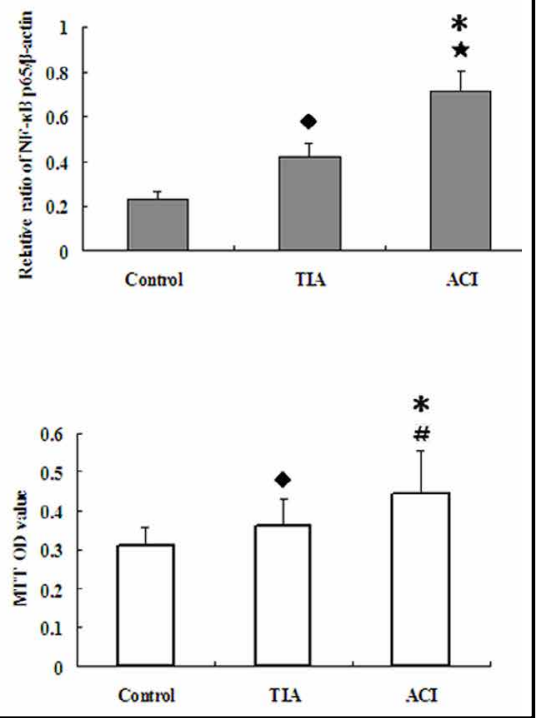

Western blot in differentiated Th17 cells from ACI, TIA and control groups. All detected proteins were normalized to PCNA, and ratios of NF-KB p65/PCNA for the gray-scale value were compared in three groups. The data were representative of three experiments, and expressed as mean $\pm \mathrm{SD}^{*} P<0.01$ vs. Control; $\bullet^{*}<0.05$ vs. Control; ${ }^{\star} P<0.01$ vs. TIA. (C) BrdU and MTT incorporation for Th17 proliferation induced by $1.0 \mu \mathrm{g} / \mathrm{ml}$ ox-LDL in the ACI, TIA and control groups. ${ }^{*} P<0.01$ vs. Control; ${ }^{\bullet} P<0.05$ vs. Control; $\# P<0.05$ vs. TIA.

Effects of ox-LDL on Fas-mediated apoptosis in Treg/Th17 cells from ACI patients in vitro

After incubation with $1 \mu \mathrm{g} / \mathrm{ml}$ ox-LDL for $48 \mathrm{~h}$, the elevation of AnnexinV ${ }^{+}$apoptotic Treg cells in ACI patients (53.52 $\pm 7.61 \%$ ) was significantly higher than that in TIA patients $(31.73 \pm 5.82 \%)$ and control subjects $(18.64 \pm 3.25 \%)$ (both $P<0.01)$. Apoptotic Treg cells in TIA patients were also significantly higher than those in the control group $(P<0.05)$. Moreover, there were no significant differences in apoptotic Th17 cells between the three groups $(5.21 \pm 1.63 \%$ for control group, $5.42 \pm 1.31 \%$ for TIA group, $6.05 \pm 1.96 \%$ for ACI group) (all $P>0.05$, Fig. 5A).

The levels of Fas/FasL expression and Caspase-3 activity for Treg cells were markedly higher in the ACI group $(61.42 \pm 8.53 \%$ for Fas, $12.17 \pm 3.86 \%$ for FasL, $57.31 \pm 8.91 \%$ for Caspase-3) than those in the TIA ( $40.61 \pm 6.45 \%$ for Fas, $7.93 \pm 2.12 \%$ for FasL, $35.23 \pm 6.82$ $\%$ for Caspase-3) and the control group (23.57 $\pm 4.31 \%$ for Fas, $4.34 \pm 1.05 \%$ for FasL, 18.34 $\pm 3.73 \%$ for Caspase- 3 ) ( $P<0.01, P<0.05$ respectively). In addition, Fas/FasL expression and Caspase- 3 activity for Treg cells in the TIA group were also significantly higher than those in the control group $(P<0.01$ respectively). Interestingly, there were no significant differences in Fas/FasL expression and Caspase-3 activity for Th17 cells among the three 
groups (control: $6.37 \pm 1.81 \%$ for Fas, $2.13 \pm 0.65 \%$ for FasL, $5.68 \pm 1.41 \%$ for Caspase-3; TIA: $6.12 \pm 1.54 \%$ for Fas, $2.21 \pm 0.53 \%$ for FasL, $5.45 \pm 1.21 \%$ for Caspase-3; ACI: $6.71 \pm$ $2.05 \%$ for Fas, $2.64 \pm 0.87 \%$ for FasL, $5.94 \pm 1.65 \%$ for Caspase-3; all $P>0.05$ ) (Fig. 5A).

Therefore, there were more significant changes of apoptosis and Fas/FasL/Caspase-3 pathway for Treg cells induced by ox-LDL in ACI patients than in TIA and control subjects. There were also more significant changes in these indicators for Treg cells in TIA patients than in control subjects. However, there were no significant alterations in apoptosis and Fas/ FasL/Caspase-3 pathway for Th17 cells among the three groups treated with ox-LDL.

\section{Effects of ox-LDL on Th17 proliferation response from ACI patients in vitro}

We investigated the sensitivity of the ox-LDL-mediated NF- $\mathrm{B}$ activition and Th17 proliferation in the ACI, TIA, and control groups in vitro. The nuclear translocation of NF$\kappa B$ induced by ox-LDL in ACI patients was strengthened markedly compared to the TIA and control groups. Moreover, NF- $\kappa B p 65$ nuclear translocation in TIA patients was increased more significantly than in the control group $(P<0.01, P<0.05$ respectively, Fig. 5B). At the same time, there were notable enhancements in BrdU and MTT incorporation induced by oxLDL in ACI patients than in TIA patients and control subjects $(P<0.01, P<0.05$ respectively). Furthermore, this proliferating effect in TIA patients was reinforced more obviously than in control subjects (all $P<0.05$, Fig. 5C).

\section{Discussion}

Ox-LDL is primarily present in atherosclerotic lesions but not in normal arteries and is associated with plaque vulnerability [25]. In the present study, significant positive and negative correlations were noted between Th17 cells, Treg cells, and serum ox-LDL levels. Ox-LDL can induce a more significant alteration of Treg apoptosis mediated by Fas/FasL pathway and Th17 proliferation correlated with NF- $\kappa B$ activation in ACI patients than in the TIA and control groups in vitro. These data indicate that ox-LDL influences Th17/Treg balance by modulating Treg apoptosis and Th17 proliferation, which may lead to thrombosis and pathogenesis of ACI.

Ox-LDL plays an important role in the promotion of AS initiation, progression and plaque destabilisation [11]. Plasma levels of ox-LDL have been reported to be high in patients with cortical ischemic damage and a predictor of enlargement of the ischemic lesion [26]. The results of a study by Fang et al [27] indicated that age and plasma ox-LDL level were possible risk factors for carotid plaque, and the ox-LDL level was associated with carotid plaque vulnerability.

The effects of ox-LDL on AS are associated with the reduced frequency and compromised suppressive function of Treg cells [28]. In our study, ox-LDL concentrations in serum were negatively correlated with the frequency of Treg cells, and positively correlated with the frequency of Th17 cells. Moreover, Treg apoptosis and Th17 proliferation from ACI patients were more susceptible to the influence of ox-LDL when compared to those in TIA and control subjects. Accordingly, elevated sensitivity to ox-LDL results in the aggravation of the Th17/ Treg imbalance, which promotes plaque inflammation and destabilisation in ACI.

Apoptosis is an important process of many pathological conditions including AS. Apoptosis disorders, both interrupted and accelerated apoptosis, were verified as central defects in immune function, and could lead to a range of diseases [29]. The combination of Fas and FasL on cell membrane triggers an activation cascade of caspases [13]. Caspase- 3 is considered to be a major executioner protease and has been shown to take an important part in the activation of the apoptotic signaling pathway. The Fas/FasL/Caspase-3 pathway plays a critical role in $\mathrm{T}$ cell apoptosis, including that of Treg and Th17 cells $[14,30]$.

An increasing body of work has shown that Fas/FasL play a critical role in the pathology of ischemic stroke [31, 32]. A study by Martín-Ventura et al. [33] has shown that a high expression of FasL and active caspase-3 in PBMCs occurs in ACI patients, which participate 
in the mechanisms underlying plaque instability in patients with carotid atherosclerosis. OxLDL can induce apoptosis in a variety of tissues and cells including smooth muscle cells and macrophages [34, 35]. Ox-LDL also induces apoptosis in human coronary artery endothelial cells, in a concentration- and time-dependent manner [36]. However, little was previously known about the sensitivity of Th17 and Treg to Fas-related apoptosis mediated by ox-LDL in ACI patients.

In our study, Treg cells in ACI patients were shown to be more sensitive to Fas-mediated apoptosis induced by ox-LDL than those in TIA patients and control groups. At the same time, Treg cells in TIA patients were also shown to be more sensitive to Fas-mediated apoptosis induced by ox-LDL than those in control groups in vitro, which suggested that Fas/FasL/ caspase-3 pathway in Treg for ACI and TIA patients is activated by the effects of ox-LDL. Interestingly, the Fas/FasL pathway did not play a role in Th17 expression induced by oxLDL. Th17 cells expressed low levels of Fas and FasL indicating no effect of Fas-mediated apoptosis on Th17 cells after treatment with ox-LDL. Here we found that Treg cells, but not Th17 cells are sensitive to ox-LDL-mediated apoptosis. Increased apoptosis of Treg cells may lead to relative reduction of Treg expression, in which the Fas/FasL pathway plays a crucial role.

Ox-LDL also has an outstanding effect on Th17 proliferation, which is associated closely with NF- $\kappa B$ activiation. The NF- $\kappa B$ signaling pathway regulates inflammatory responses and has been implicated in AS. A relevant report showed that ox-LDL upregulated NF- $\kappa B$ signaling pathway in ox-LDL-induced foam cells formation [19].

Hence, we predicted that NF- $\kappa B$ was perhaps an underlying modulator of ox-LDLstimulated proliferation of Th17 cells. To prove this hypothesis, we analyzed the nuclear translocation of NF- $\kappa B$ (p65) by western blot. Moreover, after pre-treatment with PDTC, an inhibitor of NF- $\mathrm{BB}$, Th17 proliferation was analyzed. In regard to treatment with ox-LDL at different doses for control subjects, translocation of NF- $\kappa \mathrm{B}$ (p65) was strengthened, along with Th17 proliferation advancement. Furthermore, the proliferation of Th17 was significantly inhibited by PDTC pre-treatment, confirming that Th17 proliferation was mediated through a NF- $\kappa B$-related pathway. In addition, Th17 cells in ACI patients were shown to be more responsive to NF- $\mathrm{BB}$-related proliferation induced by ox-LDL than those in TIA and control subjects, and Th17 cells in TIA patients were also shown to be more sensitive to ox-LDLinduced proliferation than those in control subjects, which suggested that NF- $\mathrm{KB}$-related proliferation in Th17 for ACI and TIA patients is activated by ox-LDL.

Ox-LDL-mediated cell apoptosis and proliferation could have been responsible for the change in the balance of Th17/Treg cells. Ox-LDL might induce Fas-mediated apoptosis signaling, resulting in the increase of apoptotic Treg cells and cell proliferation associated with NF- $\mathrm{BB}$, resulting in the amplification of Th17 cells. These pathways may alter the fragile balance between Treg and Th17 cells, leading to plaque instability and ACI occurrences. The decrease of ox-LDL levels could maintain plaque stability and prevent the onset of ACI.

Our finding needs yet to be further proven in a large scale population study, and ongoing efforts should be made to explore whether other pathways are related to Treg apoptosis, and the precise molecular mechanisms of ox-LDL on Th17 proliferation.

In conclusion, our findings show that ox-LDL may contribute to Th17/Treg imbalance by affecting Fas-mediated apoptosis for Treg cells and NF- $\kappa B$-associated proliferation for Th17 cells. The role of ox-LDL on Th17/Treg cells may provide an exciting new target on the pathogenesis and the treatment of ACI.

\section{Acknowledgments}

This study was supported by National Natural Science Foundation of China (No.81071808), Natural Science Foundation of Anhui province of China (No. 1408085MH145, 11040606Q08), and Natural Science Key Foundation of Anhui Universities of China (No. 
KJ2011A166). We thank Dr. Helen Williams (Vascular Biology Research Centre, Department of Surgery, Westmead Hospital at the University of Sydney) for critically correcting and evaluating the manuscript.

\section{References}

1 Hansson GK: Inflammation, atherosclerosis, and coronary artery disease. N Engl J Med 2005;352:1685-

1695.

2 Binder CJ, Chang MK, Shaw PX, Miller YI, Hartvigsen K, Dewan A, Witztum JL: Innate and acquired immunity in atherogenesis. Nat Med 2002;8:1218-1226.

3 Hansson GK, Libby P, Schonbeck U, Yan ZQ: Innate and adaptive immunity in the pathogenesis of atherosclerosis. Circ Res 2002;91:281-291.

-4 Parmar JP, Rogers WJ, Mugler JP 3rd, Baskurt E, Altes TA, Nandalur KR, Stukenborg GJ, Phillips CD, Hagspiel $\mathrm{KD}$, Matsumoto AH, Dake MD, Kramer CM: Magnetic resonance imaging of carotid atherosclerotic plaque in clinically suspected acute transient ischemic attack and acute ischemic stroke. Circulation 2010;122:20312038.

5 Sakaguchi S, Ono M, Setoguchi R, Yagi H, Hori S, Fehervari Z, Shimizu J, Takahashi T, Nomura T: Foxp $3^{+} \mathrm{CD} 25^{+} \mathrm{CD} 4^{+}$natural regulatory $\mathrm{T}$ cells in dominant self-tolerance and autoimmune disease. Immunol Rev 2006;212:8-27.

6 Bettelli E, Oukka M, Kuchroo VK: T(H)-17 cells in the circle of immunity and autoimmunity. Nat Immunol 2007;8:345-350.

7 Smith E, Prasad KM, Butcher M, Dobrian A, Kolls JK, Ley K, Galkina E: Blockade of interleukin-17A results in reduced atherosclerosis in apolipoprotein E-deficient mice. Circulation 2010;121:1746-1755.

-8 Xie JJ, Wang J, Tang TT, Chen J, Gao XL, Yuan J, Zhou ZH, Liao MY, Yao R, Yu X, Wang D, Cheng Y, Liao YH, Cheng X: The Th17/Treg functional imbalance during atherogenesis in ApoE(-/-) mice. Cytokine 2010;49:185-193.

9 Cheng X, Yu X, Ding YJ, Fu QQ, Xie JJ, Tang TT, Yao R, Chen Y, Liao YH: The Th17/Treg imbalance in patients with acute coronary syndrome. Clin Immunol. 2008;127:89-97.

10 Li Q Wang Y, Yu F, Wang YM, Zhang C, Hu C, Wu Z, Xu X, Hu S: Peripheral Th17/Treg imbalance in patients with atherosclerotic cerebral infarction. Int J Clin Exp Pathol 2013;6:1015-1027.

11 Mitra S, Deshmukh A, Sachdeva R, Lu J, Mehta JL: Oxidized low-density lipoprotein and atherosclerosis implications in antioxidant therapy. Am J Med Sci 2011;342:135-142.

12 Li Q Wang Y, Chen K, Zhou Q, Wei W, Wang Y, Wang Y: The role of oxidized low-density lipoprotein in breaking peripheral Th17/Treg balance in patients with acute coronary syndrome. Biochem Biophys Res Commun 2010;394:836-842.

13 Zhang Y, Xu G, Zhang L, Roberts AI, Shi Y: Th17 cells undergo Fas-mediated activation-induced cell death independent of IFN-r. J. Immunol 2008;181:190-196.

14 Li Q Wang Y, Wang Y, Zhou Q Chen K, Wang YM, Wei W, Wang Y: Distinct different sensitivity of Treg and Th17 cells to Fas-mediated apoptosis signaling in patients with acute coronary syndrome. Int J Clin Exp Pathol 2013;6:297-307.

15 Meier P, Spertini F, Blanc E, Burnier M: Oxidized low-density lipoproteins activate CD4+ T cell apoptosis in patients with end-stage renal disease through Fas engagement. J Am Soc Nephrol 2007;18:331-342.

- 16 Zettler ME, Prociuk MA, Austria JA, Austria JA, Massaeli H, Zhong G, Pierce GN: OxLDL stimulates cell proliferation through a general induction of cell cycle proteins. Am J Physiol Heart Circ Physiol 2003;284:H644-H653.

17 Chen HN, Wang DJ, Ren MY, Wang QL, Sui SJ: TWEAK/Fn14 promotes the proliferation and collagen synthesis of rat cardiac fibroblasts via the NF-кB pathway. Mol Biol Rep 2012;39:8231-8241.

18 Kang YH, Ji NY, Han SR, Lee CI, Kim JW, Yeom YI, Kim YH, Chun HK, Kim JW, Chung JW, Ahn DK, Lee HG, Song EY: ESM-1 regulates cell growth and metastatic process through activation of NF- $\mathrm{KB}$ in colorectal cancer. Cell Signal 2012;24:1940-1949.

19 Huang ZG, Liang C, Han SF, Wu ZG: Vitamin E ameliorates ox-LDL-induced foam cells formation through modulating the activities of oxidative stress-induced NF- $\kappa$ B pathway. Mol Cell Biochem 2012;363:11-19. 
20 Fure B, Wyller TB, Thommessen B: TOAST criteria applied in acute ischemic stroke. Acta Neurol Scand 2005;112:254-258.

21 Easton JD, Saver JL, Albers GW, Alberts MJ, Chaturvedi S, Feldmann E, Hatsukami TS, Higashida RT, Johnston SC, Kidwell CS, Lutsep HL, Miller E, Sacco RL: Definition and evaluation of transient ischemic attack: a scientific statement for healthcare professionals from the American Heart Association/American Stroke Association Stroke Council; Council on Cardiovascular Surgery and Anesthesia; Council on Cardiovascular Radiology and Intervention; Council on Cardiovascular Nursing; and the Interdisciplinary Council on Peripheral Vascular Disease: the American Academy of Neurology affirms the value of this statement as an educational tool for neurologists. Stroke 2009;40:2276-2293.

22 Mor A, Luboshits G, Planer D, Keren G, George J. Altered status of CD4+CD25+ regulatory T cells in patients with acute coronary syndromes. Eur Heart J 2006;27:2530-2537.

23 Roy Chowdhury SK1, Sangle GV, Xie X, Stelmack GL, Halayko AJ, Shen GX. Effects of extensively oxidized low-density lipoprotein on mitochondrial function and reactive oxygen species in porcine aortic endothelial cells. Am J Physiol Endocrinol Metab 2010;298:E89-E98.

-24 Sobal G, Menzel JE, Sinzinger H. Influence of acetylsalicylic acid on oxidationof native and glycated lowdensity lipoprotein. Life Sci 2000;66:1987-1998.

25 Nishi K, Itabe H, Uno M, Kitazato KT, Horiguchi H, Shinno K, Nagahiro S: Oxidized LDL in carotid plaques and plasma associates with plaque instability. Arterioscler Thromb Vasc Biol 2002; 22:1649-1654.

-26 Uno M, Harada M, Takimoto O, Kitazato KT, Suzue A, Yoneda K, Morita N, Itabe H, Nagahiro S: Elevation of plasma oxidized LDL in acute stroke patients is associated with ischemic lesions depicted by DWI and predictive of infarct enlargement. Neurol Res 2005;27:94-102.

27 Fang R, Zhang N, Wang C, Zhao X, Liu L, Wang Y, Xu J, Wang X, Liu Z, Wang Y: Relations between plasma oxLDL and carotid plaque among Chinese Han ethnic group. Neurol Res 2011;33:460-466.

28 Mor A, Planer D, Luboshits G, Afek A, Metzger S, Chajek-Shaul T, Keren G, George J: Role of naturally occurring $\mathrm{CD} 4{ }^{+} \mathrm{CD} 25^{+}$regulatory $\mathrm{T}$ cells in experimental atherosclerosis. Arterioscler Thromb Vasc Biol 2007;27:893-900.

-29 Szuster-Ciesielska A, Daniluk J, Bojarska-Junak A: Apoptosis of blood mononuclear cells in alcoholic liver cirrhosis. The influence of in vitro ethanol treatment and zinc supplementation. Toxicology 2005;212:124134.

30 Fang Y, Yu S, Ellis JS, Sharav T, Braley-Mullen H: Comparison of sensitivity of Th1, Th2, and Th17 cells to Fas-mediated apoptosis. J Leukoc Biol 2010; 87:1019-1028.

-31 Rosenbaum DM, Gupta G, D'Amore J, Singh M, Weidenheim K, Zhang H, Kessler JA: Fas (CD95/APO-1) plays a role in the pathophysiology of focal cerebral ischemia. J Neurosci Res 2000;61:686-692.

-32 Jia J, Guan D, Zhu W, Alkayed NJ, Wang MM, Hua Z, Xu Y: Estrogen inhibits Fas-mediated apoptosis in experimental stroke. Exp Neurol 2009;215:48-52.

-33 Martín-Ventura JL, Blanco-Colio LM, Muñoz-García B, Gómez-Hernández A, Arribas A, Ortega L, Tuñón J, Egido J: NF-kappaB activation and Fas ligand overexpression in blood and plaques of patients with carotid atherosclerosis: potential implication in plaque instability. Stroke 2004;35:458-463.

34 Kataoka H, Kume N, Miyamoto S, Minami M, Morimoto M, Hayashida K, Hashimoto N, Kita T: Oxidized LDL modulates Bax/Bcl-2 through the lectin-like Ox-LDL receptor-1 in vascular smooth muscle cells. Arterioscler Thromb Vasc Biol 2001;21:955-960.

-35 Hardwick SJ, Hegyi L, Clare K, Law NS, Carpenter KL, Mitchinson MJ, Skepper JN: Apoptosis in human monocyte-macrophages exposed to oxidized low-density lipoprotein. J Pathol 1996;179:294-302.

-36 Chen J, Mehta JL, Haider N, Zhang X, Narula J, Li D: Role of Caspases in Ox-LDL-Induced Apoptotic Cascade in Human Coronary Artery Endothelial Cells. Circulation Research 2004;94:370-376. 